\title{
The Readiness for Moving toward Digital Thailand - A Case Study
}

\author{
Wasinee Noonpakdee, Acharaphun Phothichai, and Thitiporn Khunkornsiri
}

\begin{abstract}
The digital economy, which is a new economy represented by the inclusion of technology and digital information, has become a dominant force in today's economy. In Thailand, there is an urgent need to leverage digital technology to drive the country forward. Therefore, Digital Thailand Plan is developed to generate social stability and economic wealth in Thailand. This paper presents a study of readiness for moving toward Digital Thailand, a case study in a government sector. The research process consists of three stages: 1) Literature review 2) An in-depth Interview of top-management officers in eight government agencies 3) Analysis and conclusion. In this paper, the readiness for moving toward Digital Thailand is analyzed regarding Information System management, E-Government Service, Staff, Data Management, Digital Technology and Infrastructure, and Organization's culture.
\end{abstract}

Index Terms-Digital economy, digital government, readiness.

\section{INTRODUCTION}

The use of information and information technology in the economy allows companies to be competivive. Many economy sectors or industies applied Information and Communications Technology (ICT) to create new products and services such as automotive industry, telecomunication industry, energy sector, financial sector, and service sector [1]. Digital economy is the recent way of doing business with the help of ICT, especially the Internet [2]. It is a new economy represented by the inclusion of technology and digital information [3]. The digital economy is a dominant force in today's economy, and is sometimes called the new economy or the Internet economy [4]. There is an opportunity for a country to transform the economy and to contribute to the development of the digital economy [5].

In Thailand, extensive reformation in all socio-economic dimensions is undertaken. There is an urgent need to leverage digital technology to drive the country forward. Consequently, Digital Thailand Plan is developed to generate social stability and economic wealth in Thailand [6]. This research aims to study the readiness for moving toward Digital Thailand, a case study in government sector. The results can be a guideline for preparing Digital Thailand Plan to create social stability and economic wealth.

The rest of this paper is organized as follows. Section II presents literature review of Digital Thailand, Digital Government, and Research framework. In Section III,

Manuscript received March 21, 2017; revised September 4, 2017.

The authors are with the College of Innovation, Thammasat University, 2 Phrachan Road, Bangkok, Thailand (e-mail: wasinee@citu.tu.ac.th). research methodology is provided. The results of this research are described in Section IV. Finally, Section V concludes the paper.

\section{LITERATURE REVIEW}

\section{A. Digital Thailand}

Digital Thailand Plan is developed by Ministry of Information and Communication Technology (MICT) and Ministry of Science and Technology (MOST) as a digital blueprint to revolutionize government operations, business practices, and people's lifestyle. The objective of this plan is to generate social stability and economic wealth in Thailand The plan consists of six strategies which are: 1) Build country-wide high-capacity digital infrastructure, 2) Boost the economy with digital technology, 3) Create a quality and equitable society through digital technology, 4) Transform into digital government, 5) Develop workforce for digital era, and 6) Build trust and confidence in the use of digital technology [6].

\section{1) Build country-wide high-capacity digital infrastructure}

In this strategy, high-quality broadband will be rolled out country-wide. Broadband subscription rate will be priced under $2 \%$ of GNP per Capita. Thailand will become one of the Internet connectivity hubs. Mobile services will be provided in all communities.

\section{2) Boost the economy with digital technology}

The goals of this strategy is to increase overall competitiveness of Thai businesses. More SMEs in agriculture, manufacturing, service sectors will leverage digital technology to compete regionally and globally. Thailand will be placed in the top 30 of the World Competitiveness. Digital sector will contribute at least one-fourth of the country's GDP. Thailand's digital industry will become one of the regional leaders.

3) Create a quality and equitable society through digital technology

In this strategy, people of all groups and abilities will be able to access and make use of digital technology. All Thais will become digitally literate. Education, healthcare, and essential public services will be accessed via digital means.

\section{4) Transform into digital government}

Government services will meet the demands of people and businesses with respect to convenience, speed, and accuracy. People will be able to easily access government data to ensure transparency and civic participation. Government infrastructure and data will be integrated to link 
governmental functions and provide effective services to the people.

\section{5) Develop workforce for digital era}

Digital specialists, especially in highly-needed categories, will be developed in both quantity and quality. New jobs and new businesses will be generated. Workforce in all sectors will become digitally competent.

\section{6) Build trust and confidence in the use of digital technology}

People will have trust and confidence in online transactions. Digital laws and regulations will be updated to meet the demands of the digital era. Data standards will be introduced and implemented to ensure seamless online transactions.

\section{B. Digital-Government}

E-government has emerged in public administration to apply ICT for supporting governments in information and service delivery, efficiency and effectiveness, interactivity, decentralization, transparency, and accountability and also to offer a one-stop services for stakeholders [7], [8]. Instead of e-government, the term can be called 'digital government' or 'virtual state' [8], [9].

In Thailand, Digital government development plan is developed in order to determine the direction of raising digital capacity of the government to be unified and concrete. Moreover, the drive for Thai government toward Digital government is one of the key strategies of Digital Thailand Plan. Digital government development plan comprises four main strategies which are 1) Development of the digital capacity toward Digital Government, 2) Development of People's Quality of Life, 3) Maximized Competitiveness of the Business Sector, and 4) Advancement of Public Security [10].

The first strategy, Development of the digital capacity toward Digital Government, contains six measures which are Data integration, Verification and authorization via Smart Card, One stop service, Proactive complain resolution and need access, Electronic Services Infrastructure, and Government Personnel's Competency Development.

In the second strategy, Development of People's Quality of Life, the measures are Proactive integrated services to support the citizen, and integrated labor market.

The measures of the third strategy, Maximized Competitiveness of the Business Sector, are integrated agriculture, integrated tourism, integration of cross-sector investment services, integration of import-export, proactive SME Promotion to support the growth, and integrated Cross-organization Tax System.

Finally, the fourth strategy, Advancement of Public Security, includes four measures which are Proactive Public Security Using Analysis Tools, Advance Passenger Identification and Passenger Risk Assessment, Integrating Information to Prevent Natural Disasters, and Integrating Information among Agencies for Crisis Management.

\section{Conceptual Framework}

The worldwide e-government development has passed many different phases, and can be seen from E-government annual benchmarking by several international institutions.
The information readiness and availability is important to improve e-government policies and strategies [11], [12].

In this research, the readiness for moving forward Digital Thailand is divided into six modules: Information System management, E-Government Service, Staff, Data Management, Digital Technology and Infrastructure, and Organization's culture. The conceptual framework is illustrated in Fig. 1.

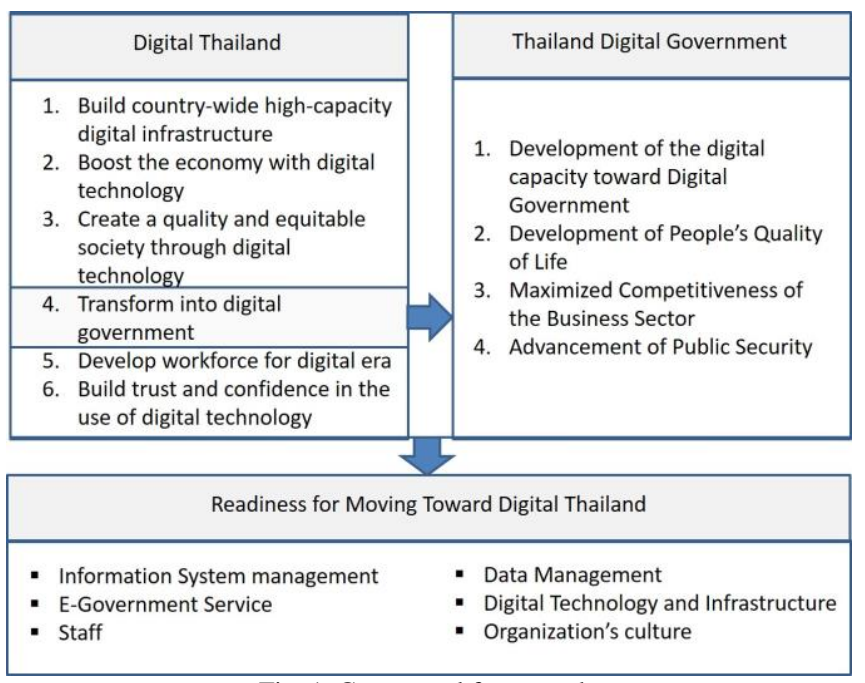

Fig. 1. Conceptual framework.

\section{1) Information system management}

Information management is the basis of the emerging concept of network economy, e-economy, specifically, economic activities that are performed via digital telecommunications. [13].

This part emphasizes on the information system of operational management or management of information resources of the organization such as PM (Project Management), ERP (Enterprise Resource Planning), CRM (Customer Relationships Management), SRM (Supplier Relationships Management), SCM (Supply Chain Management), or EAM (Enterprise Asset Management).

\section{2) E-government service}

E-Government simply refers to the use of ICT to deliver government services to its citizen [14]. There are three main classifications of e-government systems: government to government (G2G), government to citizen (G2C), and government to business (G2B) [7], [15].

3) Staff

A well-trained and motivated workforce is critical to the success of E-Government [16]. The human capital of a country reflects the extent to which the population is literate and has attained an adequate level of education [17]. Information literacy, which is the ability to effectively use digital media to access, create, manage and evaluate information, plays an important role in today's digital society [18].

\section{4) Data management}

The availability and access to government information should be top priority for every government [19]. Regarding data architecture, there are several general patterns and principles that are key to the operation such as Data 
ownership, Service unit groups, Data encapsulation, Data sharing, Access locking, Legacy systems, Outsourcing, Legal records, and Data compatibility [20].

\section{5) Digital technology and infrastructure}

The use of digital technologies (DTs) as electronic tools for conducting transactions and services has grown considerably. DTs and tools have different architecture and comprise such tangible items like computers and computer accessories; and intangible items such as software packages, communication networks and the internet [21]. ICT infrastructure, such as broadband, has promoted networked innovation and collaboration among universities, industries, and governments. As a technological capability, the ICT infrastructure influences the development, diffusion, and use of innovations [22].

\section{6) Organization's culture.}

Organizational culture having interacted with human resource, organizational structure and controlling system has included values and beliefs; as a result, it has established behavioral norms. The culture influenced all aspects of an organization [23].

\section{RESEARCH METHODOLOGY}

This research is a qualitative research. As shown in Figure 2, the research process is composed of three stages: 1) literature review including digital Thailand and Digital Government, 2) An in-depth Interview of top-management levels in eight government agencies (G1-G8) in Thailand, and 3) Analysis and conclusion of this research. The data acquired from literature study is applied to develop a framework for the study. After In-depth interview, the analysis and conclusion is conducted.

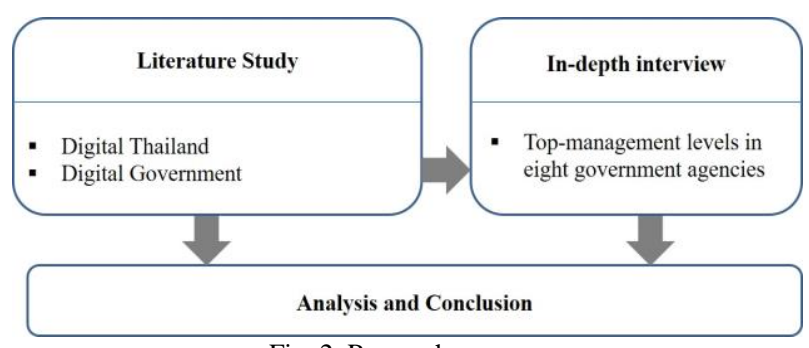

Fig. 2. Research process.

\section{RESULTS}

This section presents the result of in-depth interviews of eight government agencies on the readiness for moving forward Digital Thailand which comprised six components: Information System management, E-Government Service, Staff, Data Management, Digital Technology and Infrastructure, and Organization's culture.

\section{A. Information System Management}

We analyze how the organization apply the systems for internal resource management, and whether these systems help to work effectively or still have some problems. According to the in-depth interview, all sample organizations apply some system for their management such as ERP, e-document, e-back office. The system facilitates the work of staff and reduce operational process services. The staff involved in the process of working gradually adopted the system since there are user manuals and clear Policies.

However, there are some issues such as users do not trust the system or human error when inputting data. Therefore, some organizations are still using the paper work together with the system which is paperless. Some officers still use the traditional system (paper work) because they are familiar with the old-fashioned system. The training should be provided, and adequate help desk team should be prepared to answer some questions to solve users' issues. Some laws and regulations do not support the digital procedure. Moreover, digital system do not cover all the electronic processes, so there is a need for paper documents in conjunction with the system.

TABLE I: INTERVIEW RESULT: INFORMATION SYSTEM MANAGEMENT

\begin{tabular}{lll}
\hline \multicolumn{1}{c}{$\begin{array}{c}\text { Government } \\
\text { Agency }\end{array}$} & \multicolumn{3}{c}{ Detail } \\
\hline G1 & $\begin{array}{l}\text { System for monitoring performance and } \\
\text { expenditure. System for Project Management }\end{array}$ \\
\hline G2 & ERP, e-Document, Information Management \\
\hline \multicolumn{4}{c}{ DPIS (Departmental Personnel Information } \\
G3 & System), e-Document Systems, Internal \\
\hline G4 & Performance Agreement: IPA \\
\hline G5 & ERP, Safety management \\
\hline G6 & Information Operation system \\
\hline G7 & e-Document, e-Meeting \\
\hline G8 & e-Back office \\
\hline \hline
\end{tabular}

\section{B. E-Government Service}

Regarding the interview, all the agencies (G1 to G8) have their own websites for providing some information and services to the citizen. Some agencies plan to develop new websites and mobile applications for improving the current services and providing new services. However, some agencies that have to contact people in rural areas addressed that they still have to use telephone line (hot line) as a channel to contact the citizen since those people do not have digital literacy. Moreover, some people could not afford the digital device such as smartphone or laptop.

TABLE II: INTERVIEW RESULT: E-GOVERNMENT SERVICE

\begin{tabular}{llll}
\hline \hline \multicolumn{1}{c}{$\begin{array}{l}\text { Government } \\
\text { Agency }\end{array}$} & \multicolumn{1}{c}{ Detail } \\
\hline G1 & Website, e-Map, Sensor network & \\
\hline G2 & Website, e-Record service & \\
\hline G3 & Website, National Single & Window, & Web \\
& Application, One-stop service & \\
\hline G4 & Website & \\
\hline G5 & Website, Hotline & \\
\hline G6 & Website & \\
\hline G7 & Website, Web board, smart phone application (still \\
\hline G8 & developing) & \\
\hline \hline
\end{tabular}

\section{Staff}

The interview topics are related to skill, knowledge, attitude of the staff in the organization. The results find that there are some issues related to the generation of the staff. The older generation is difficult to change. There are some 
difficulties for this generation to use the new technology. The new generation, who are familiar with digital technology, are learning fast when compared to the older generation. In addition, change management and training should be provided.

TABLE III: INTERVIEW RESULT: STAFF

\begin{tabular}{cc}
\multicolumn{2}{c}{ TABLE III: INTERVIEW RESULT: STAFF } \\
\hline \hline $\begin{array}{c}\text { Government } \\
\text { Agency }\end{array}$ & Detail \\
\hline
\end{tabular}
lack the skills, knowledge, and attitude. Most people in the organization are older generation, and they are familiar with traditional system.

Due to the organization size which has nearly

G2 14,000 people, it may take some time for the staff to get ready for adopting the system. Training and change management would be required.

Approximately 50 percent of the staff are ready for

G3 Digital Thailand. Digital Economy has been applied in all kinds of tasks in the organization. People gradually adapt themselves to the system.

\begin{tabular}{cl} 
& People gradually adapt themselves to the system. \\
\hline G4 & $\begin{array}{l}\text { There are some difficulties for the older generation } \\
\text { to learn how to use technology. }\end{array}$ \\
\hline G5 & Staff are eager to acquire new technology. \\
& $\begin{array}{l}\text { The policy for applying digital technology was } \\
\text { issued. At first, people did not understand, and } \\
\text { there were some resistances. However, they started } \\
\text { to accept the technology when they realized the } \\
\text { benefits. }\end{array}$ \\
\hline G7 & $\begin{array}{l}\text { Some people are ready for Digital Thailand to a } \\
\text { certain extent. The clear direction and strategy are } \\
\text { required, and training is also important. }\end{array}$ \\
\hline G8 & $\begin{array}{l}\text { Most staff have some skills and knowledge for } \\
\text { digital technology. However, the number of staff is } \\
\text { not sufficient. }\end{array}$ \\
\hline \hline
\end{tabular}

\section{Data Management}

The interview considers how agencies manage the data lifecycle process properly. This includes data governance and data analysis. According to the results, data integration has not been fully implemented yet. Some agencies shares data only in the organization. For data analysis, some organization apply data analysis to help improve efficiency and make better decision.

TABLE IV: INTERVIEW RESULT: DATA MANAGEMENT

\begin{tabular}{ll}
\hline \multicolumn{1}{c}{$\begin{array}{c}\text { Government } \\
\text { Agency }\end{array}$} & $\begin{array}{l}\text { The organizations share data with other } \\
\text { organizations, both government agencies and other } \\
\text { agencies. The information is used for managing the } \\
\text { organization and for data integration. }\end{array}$ \\
\hline G2 & $\begin{array}{l}\text { There are some applications of data sharing and } \\
\text { data analysis. }\end{array}$ \\
\hline G3 & $\begin{array}{l}\text { Disclosure of data is according to Information Act, } \\
\text { and data is accessed within the user's right (access } \\
\text { control). The data is shared among related } \\
\text { organization. The data analysis is applied for } \\
\text { practical use. }\end{array}$ \\
\hline G4 & $\begin{array}{l}\text { Open data is done among related organization. } \\
\text { Data analysis is applied in the organization. }\end{array}$ \\
\hline G5 & Data is shared only in the organization. \\
\hline G7 & $\begin{array}{l}\text { Data is disclosed under the information act, and } \\
\text { sharing data is done among related organization. }\end{array}$ \\
\hline
\end{tabular}

\begin{tabular}{|c|c|}
\hline $\begin{array}{c}\text { Government } \\
\text { Agency }\end{array}$ & Detail \\
\hline G8 & $\begin{array}{l}\text { Data is shared with other organizations. Some type } \\
\text { of data is confidential and needed to be treated } \\
\text { carefully. Data is analyzed in many dimensions. } \\
\text { Cooperation with other agencies is required in } \\
\text { order to obtain data for analysis. }\end{array}$ \\
\hline
\end{tabular}

\section{E. Digital Technology and Infrastructure}

Digital Technology and Infrastructure comprise hardware, software, networks, and related equipment used to manage and support digital technology services in the organization. According to the interview, many agencies have infrastructure that is ready for moving forward digital Thailand. Some agency provides cloud computing network and high speed internet. However, for some agencies, the internet is not available everywhere especially in the rural area. If there are some events outside the office, one need to carry the paper documents. Furthermore, the interviewee suggested the central government to support the integration of government infrastructure.

TABLE V: INTERVIEW RESULT: DIGITAL TECHNOLOGY AND INFRASTRUCTURE

\begin{tabular}{ll}
\hline \multicolumn{1}{c}{$\begin{array}{l}\text { Government } \\
\text { Agency }\end{array}$} & \multicolumn{1}{c}{ Detail } \\
\hline G1 & $\begin{array}{l}\text { The Infrastructure in the organization such as } \\
\text { Hardware, Software, Network, and Internet is } \\
\text { ready for moving toward digital Thailand. }\end{array}$ \\
\hline & $\begin{array}{l}\text { The infrastructure is ready to a certain degree. } \\
\text { Since the organization is very big and has a lot of } \\
\text { branches, there are many projects for providing } \\
\text { infrastructure that need to be completed. For } \\
\text { example, the project that expands the network for } \\
\text { core switch, and building workgroup switch. The } \\
\text { network service for operation building, etc. }\end{array}$ \\
\hline
\end{tabular}

G3

Hardware, Software, Network, and Internet are provided within the organization. The organization is also providing cloud computing network.

\begin{tabular}{|c|c|}
\hline G4 & $\begin{array}{l}\text { The infrastructure is ready. Although there is not } \\
100 \text { percent readiness, the organization has a plan } \\
\text { to improve infrastructure in the future. }\end{array}$ \\
\hline G5 & $\begin{array}{l}\text { The infrastructure is ready to a certain degree, but } \\
\text { not } 100 \text { percent. }\end{array}$ \\
\hline G6 & $\begin{array}{l}\text { The infrastructure is not ready since there is no } \\
\text { integration between the related organizations. The } \\
\text { integration should be supported by central } \\
\text { government. }\end{array}$ \\
\hline G7 & $\begin{array}{l}\text { The infrastructure is not } 100 \text { percent ready. First, } \\
\text { the central government's infrastructure should be } \\
\text { implemented. Then, other agencies will follow the } \\
\text { central government in the same direction. }\end{array}$ \\
\hline G8 & $\begin{array}{l}\text { The infrastructure is ready, especially the network } \\
\text { provided by organization and GIN (Government } \\
\text { Information Network). }\end{array}$ \\
\hline
\end{tabular}

\section{F. Organization's Culture}

Some agencies have organization's culture that do not support moving forward Digital Thailand. Many agencies addressed that top management support is one of the most important factors affecting the readiness in digital economy. 
TABLE VI: INTERVIEW RESULT: CULTURE

\begin{tabular}{ll}
\hline \multicolumn{1}{c}{$\begin{array}{c}\text { Government } \\
\text { Agency }\end{array}$} & Detail \\
G1 & $\begin{array}{l}\text { Some organization's cultures are not ready for } \\
\text { moving forward Digital Thailand, such as old-style } \\
\text { working method of older generation. }\end{array}$ \\
\hline G2 & $\begin{array}{l}\text { Change management is required in the } \\
\text { organization. }\end{array}$ \\
\hline G3 & $\begin{array}{l}\text { Top management supports the adoption of digital } \\
\text { technology in the organization. }\end{array}$ \\
\hline G4 & $\begin{array}{l}\text { The baby boom generation has some difficulties to } \\
\text { prepare for working with digital technology. }\end{array}$ \\
\hline G5 & $\begin{array}{l}\text { The organization has a culture that the } \\
\text { subordinates respect and obey the superiors. If the } \\
\text { top management supports digital policy, the } \\
\text { organization would definitely move toward digital } \\
\text { Thailand. }\end{array}$ \\
\hline G6 & $\begin{array}{l}\text { There should be a clear policy, model, and some } \\
\text { budgets to drive for moving toward digital } \\
\text { Thailand. }\end{array}$ \\
\hline
\end{tabular}

\section{CONCLUSION}

The purpose of this research is to study the readiness for moving toward Digital Thailand, a case study in government sector. Digital Thailand Plan is developed as a digital blueprint to revolutionize government operations, business practices, and people's lifestyle. One of the strategies of this plan is transforming into digital government. Government services have to be developed in order to meet the demands of people and businesses respecting convenience, speed, and accuracy.

According to the in-depth interview and analysis, the sample government agencies are rather ready to move forward Digital Thailand, considering Information System management, E-Government Service, Staff, Data Management, Digital Technology and Infrastructure, and Organization's culture. There are some issues that need to be handled which are rules and regulations to support digital procedures, data integration and governance, digital divide, and digital literacy. Furthermore, training and change management should be provided in the organization.

The future research is to consider this framework regarding the readiness of Digital Thailand focusing on both government and private sectors. Moreover, the quantitative research could be conducted to confirm factors affecting the readiness. The results of this research can be applied as a guideline for the preparation of Digital Thailand or digital economy plan in other countries to establish social stability and economic wealth.

\section{REFERENCES}

[1] L. F. Garifova, "Infonomics and the value of information in the digital economy," Procedia Economics and Finance, vol. 23, pp. 738-743, 2015.

[2] L. Zekanovic-Korona and J. Grzunov, "Evaluation of shared digital economy adoption: Case of Airbnb," in Proc. 2014 37th International Convention on Information and Communication Technology, Electronics and Microelectronics (MIPRO), 2014, pp. 1574-1579.
[3] M. Kajtazi, "Information asymmetry in the digital economy," in Proc. 2010 International Conference on Information Society (i-Society), 2010, pp. $135-142$

[4] N. Hamid and F. Khalid, "Entrepreneurship and innovation in the digital economy," Lahore Journal of Economics, vol. 21, p. 273, 2016

[5] V. Lazovic and T. Đuričković, "The digital economy in developing countries-challenges and opportunities," in Proc. 2014 37th International Convention on Information and Communication Technology, Electronics and Microelectronics (MIPRO), 2014, pp. 1580-1585.

[6] Ministry of ICT, "Thailand digital economy and development plan," Thailand, 2016.

[7] D. Stefanovic, U. Marjanovic, M. Delić, D. Culibrk, and B. Lalic, "Assessing the success of e-government systems: An employee perspective," Information \& Management, vol. 53, pp. 717-726, 2016.

[8] M. Yildiz, "E-government research: Reviewing the literature, limitations, and ways forward," Government Information Quarterly, vol. 24, pp. 646-665, 7// 2007.

[9] J. E. Fountain, Building the Virtual State: Information Technology and Institutional Change Washington, DC: Brookings Institution Press, 2001.

[10] Electronic Government Agency, "Three-year Thailand digital government development plan," Thailand, 2016.

[11] A. Supriyanto and K. Mustofa, "E-gov readiness assessment to determine e-government maturity phase," in Proc. 2016 2nd International Conference on Science in Information Technology (ICSITech), 2016, pp. 270-275.

[12] M. Shareef, A. Ojo, and T. Janowski, "A readiness assessment framework for e-government planning: Design and application," presented at the 2nd International Conference on Theory and Practice of Electronic Governance, Cairo, Egypt, 2008.

[13] S. Y. Eroshkin, N. A. Kameneva, D. V. Kovkov, and A. I. Sukhorukov, "Conceptual system in the modern information management," Procedia Computer Science, vol. 103, pp. 609-612, // 2017.

[14] N. L. M. Noor, A. F. Harun, W. A. W. Adnan, F. M. Saman, and M. A. M. Noh, "Towards the conceptualization of citizen user experience: Citizens' preference for emotional design in E-Government portal," in Proc. 2016 4th International Conference on User Science and Engineering (i-USEr), 2016, pp. 69-74.

[15] Y.-S. Wang and Y.-W. Liao, "Assessing egovernment systems success A validation of the DeLone and McLean model of information systems success," Government Information Quarterly, vol. 25, pp. 717-733, $10 / / 2008$.

[16] P.-L. Sun, C.-Y. Ku, and D.-H. Shih, "An implementation framework for e-government 2.0," Telematics and Informatics, vol. 32, pp. $504-520,8 / / 2015$

[17] A. Das, H. Singh, and D. Joseph, "A longitudinal study of e-government maturity," Information \& Management.

[18] M. Senkbeil and J. M. Ihme, "Motivational factors predicting ICT literacy: First evidence on the structure of an ICT motivation inventory," Computers \& Education, vol. 108, pp. 145-158, 5// 2017.

[19] A. Yannoukakou and I. Araka, "Access to government information Right to information and open government data synergy," Procedia Social and Behavioral Sciences, vol. 147, pp. 332-340, 2014/08/25 2014.

[20] F. A. Cummins, "Chapter 6 - Enterprise data management," Building the Agile Enterprise (Second Edition), Boston: Morgan Kaufmann, 2017, pp. 183-208.

[21] E. O. Ibem and S. Laryea, "Survey of digital technologies in procurement of construction projects," Automation in Construction, vol. 46, pp. 11-21, 10// 2014.

[22] S. Lee, Y. Nam, S. Lee, and H. Son, "Determinants of ICT innovations: A cross-country empirical study," Technological Forecasting and Social Change, vol. 110, pp. 71-77, 9// 2016.

[23] G. A. Ahmady, A. Nikooravesh, and M. Mehrpour, "Effect of organizational culture on knowledge management based on denison model," Procedia - Social and Behavioral Sciences, vol. 230, pp. 387-395, 9/12/2016.

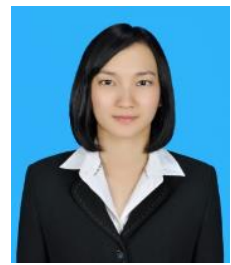

Wasinee Noonpakdee received her B.E. degree in electrical engineering from Chulalongkorn University, Thailand, in 1999, the M.ISM. degree in information systems management from Carnegie Mellon University, USA, in 2004, and the D.Sc. degree in information and telecommunications from the Graduate School of Global Information and Telecommunication Studies (GITS), Wased 
University, Japan, in 2012. From 1999 to 2003, she worked as an engineer in TelecomAsia Corporation, a telecommunication enterprise in Thailand. From 2004 to 2008, she was a computer science officer, Department of Corrections, Ministry of Justice, Thailand. Currently, she is a lecturer at Thammasat University, Thailand. Her research interests include optical wireless communications, information system management, knowledge management, and data analysis.

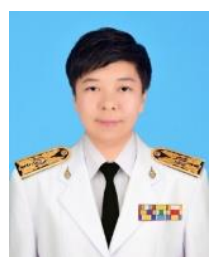

Acharaphun Phothichai received her B.E. degree in computer engineering from Rangsit University, Thailand, in 1998, and M.Sc. degree in IT Policy and management from Thammasat University, Thailand, in 2014. Her research interests include project management, information system management, knowledge management, and business analytics.

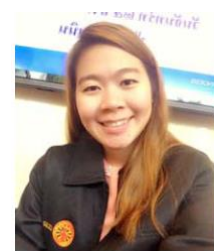

Thitiporn Khunkornsiri received her B.BA. degree in accounting from Assumption University, Thailand, in 2012, and M.Sc. degree in IT Policy and management from Thammasat University, Thailand, in 2014. Her research interests include information system management, knowledge management, and business intelligence. 